Running Head: TRANSNATIONAL MIGRATION

\title{
Transnational Migration: Gender, Remittances and Women Empowerment in India
}

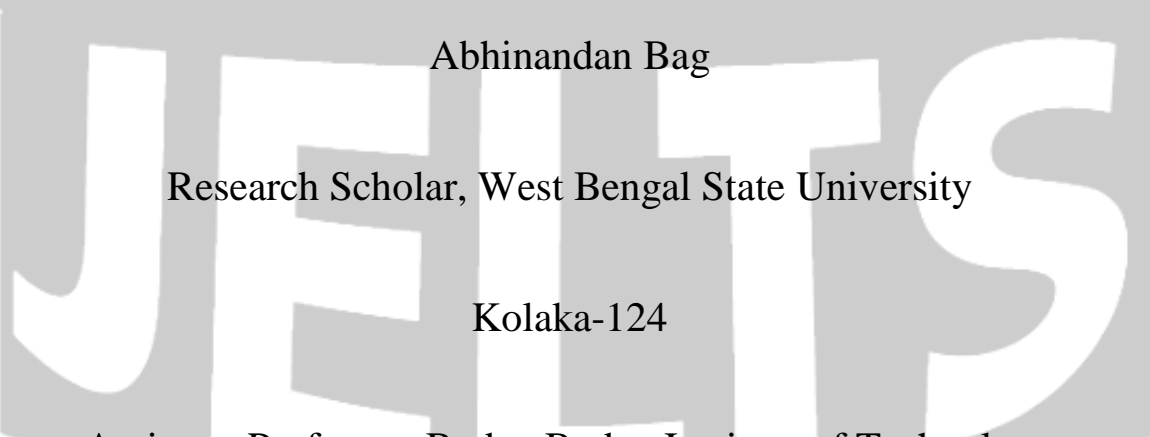

Assistant Professor, Budge Budge Institute of Technology

Kolkata-137 
According to The Economist, in 1907 USA sent 6 billion dollars through 2625 agents in grocers, backers and other shops. Recent estimates of global remittances sent by migrants are 715 billion USD and India is the top receiver of remittances claiming more than $12 \%$ of world's remittances in 2015 . Due to its large Diaspora, India consecutively remains the top receiver of remittances with 80 billion USD in 2018, 65.3 billion USD in 2017 and 62.7 billion in 2016. The ministry of Overseas India Affairs reports that, India receives remittances from approximately 35 million members of the Indian Diaspora. This crossborder money transfer is not a new phenomenon; it can be traced back to medieval India. Hundis were used as a form of remittance instrument to transfer money from place to place as a form of credit instrument or to borrow money and as a bill of exchange in trade transaction. The Reserve Bank of India describes Hundi as an unconditional order in writing made by a person directly to another to pay a certain sum of money to a person named in order. The British government in India, regarded Hundi as a traditional form of monetary transaction. They were reluctant to interfere with it as it formed an important part of Indian Economy and they wished to tax the transactions taking place within the system.

Professor Stephen Vertovec says, 'clearly these have always been significant economic aspects of migration and Transnationalism, yet economic aspects of Transnationalism may have myriad consequences' (Vertovec). Money shapes and is shaped by social relationships and cultural values, it is for the market as well as for personal life. In the words of Supriya Singh we must 'therefore to go beyond the "hostile worlds" approach that dominates the study of money in personal life and money in the market' (Singh). The management and flow of currency is an important factor for studying the Transnational gender dynamics. This plays out in different ways across cultures, but the focus on the gender of money remains important. Remittances help to study transnational movements, flow of money and structures of transnational families. They often judge the connection between the Transnational and the place of their 
origin. Money is sent by all types of Transnational workers: male-female, undocumented-documented, manual-highly skilled workers through banks, online, through professional couriers, or through social networks. It supports the financial sectors through bank deposits and credit to the private sector. At the household level, the recipients often depend on remittances to cover daily living expenses, to provide a cushion against emergencies or to make investments in business or education. Remittances improve the economic and social condition of the families in developing countries. The entire communities are transformed and primary survival of families revolves around transnational money transfer. This effects the bigger socio-cutural institutions like gender relations, marriage patterns and consumer habit.

The transnational movement from India to Gulf is by and large a Kerala phenomenon. Most of the migrant are men but there are also a population of women working as nurses, and domestic help. In the past the migrants had the opportunity to settle down but now the migrants have to return home after their contract expires. It has been observed that the adivasis have seldom migrated due to the lack of resources and contacts. The last decades witnessed an increase in the number of women migrants as the demand increased in the domestic sector. They are the most vulnerable as they work in the informal sector and usually live in the employer's house. The housemaids and the nurses are often exploited both mentally and physically. Thus the Indian government has imposed restrictions on the emigration of women below the age of 30 seeking domestic work abroad. But the poor women are willing to take the risk and they often engage themselves in transnational domestic jobs despite of the 'existing horror stories about how the female migrants can be treated in the Gulf countries' (Reshmi and Unisa).

Other than the nurses and the nannies that live in their employer's house, the Gulf has become an 'extension of the village life in Kerala' (Osella and Osella). The Malayalee community communicates 
together; share food items that are popular in Kerala, exercise cultural practices together and thus their ethnic backdrop remain intact during their stay in the Gulf. This condition of 'making home abroad from home' may also help in easing their return migration. The return migration is also different for different people. Some return after achieving their goals and some return with shattered dreams. Some return after short uninterrupted stay while others after passing long traumatic years abroad. But in both cases they do not get back the same family they left behind. The children are generally grown up, the elderly family members are generally dead. The women migrate to build up a stable future for their children but often miss their childhood. In some cases the children do not really known their returning transnational mother. Zachariah and Ranjan in their work 'From Kerala to Kerala via the Gulf: Emigration Experiences of Return Emigrants', explained how the wives want their daughters to get married to men who live in Kerala and who do not plan to migrate. Most of the time the Transnationals love to return home from abroad as the human cost of transnational movement is substantial. Zachariah and Ranjan's research also revealed how some women found returning home to the village difficult because he had become used to new routine after working almost twenty years in Saudi Arabia. They cannot have their privacy or cleanliness at home which they had abroad. Migration leads to modification in the structure of the family life where families have to make adjustments in their lifestyle and as a result of men's migration the women have to shoulder heavier workloads and more responsibilities. According to the social norms the young wives of the migratory transnationals have to live with her parent-in-law. This extended family is a protection for the new wife as well as controlling unit for her freedom. As long as she is living with the in-laws she has a little control over her own life. Family, conflict and age may allow her to move into her own house brought or built with the remittances from her husband. The mature wives often act as the 'de facto head of the family' (Chant). After handling the huge amount of remittances the woman faced new 
challenges that they have never faced before. Leela Gulati says 'the management of household expenses is no ordinary considered the responsibility of a woman, although her participation may be substantial' (Gulati). In the absence of husband the women has to manage bills and bank accounts. Thus transnational movements enhances women's agency concerning control over money. Berit Helene Vandsemb in her article “Gender Work and Social change: Return Migration to Kerala' interviewed some women who believe that learning to deal with the bank especially as a good thing. In this way, male migration extends women's agency concerning control over money. The question is whether this extended agency will continue after the return of their men, when the women have to deal with the influence and interference of returned husbands. He might be perceived alternately as 'an intruder into her daily routines, or as a savior who can take over difficult responsibilities such as disciplining the children, managing the household economy and dealing with the local authorities' (Vadsemb 82). Transnational migration has improved standard of living: housing, electricity and household appliances. Women' Performing household chorus is now easy, thereby digging out some time for personal activity. This extra time may enhance woman's agency i.e. they may get more time to socialize, involve them in decision making with the family and beyond.

Some women exercise their free will to migrate to the Gulf and thereby defying their socially assigned gender roles. Traditionally men are seen as the providers; but women migrants have become the new providers. In this new scenario sometimes men give up their jobs because their income is so small compared to what the wife is earning in the Gulf. Furthermore, when women's remittances enhance the economy of the family they begin to see her as the redeemer. Thus she gains importance in her family as well as in the society with responsibilities increased. However, these gender roles are very complex and difficult to understand. Gamburd in his work The Kitchen Spoon's Handle: Transnationalism and Sri 
Lanka's Migrant Housemaids, found that women's labour migration did not immediately or directly change women's roles in the family or village. Women who migrate for domestic services do not move with their families; they have to leave their children and husbands back at home. Thus, these mothers have to face the 'dilemma of feeling guilty for leaving their children behind, even if doing so is motivated by a strong desire to give their children a better future' (Gamburd). This feeling of guilt may spur a woman to return home earlier than planned. Generally the experience of migration and return is contradictory and self-conflicting for a woman. They often do not know whether to feel proud for earning a lot of money or to feel sorry to for leaving children behind. The women also experience the possible traumas caused by harassment or abuse. Kottegoda's study from Sri Lanka shows that 'the experiences of coming home may vary greatly between women facing separation or dysfunctional families, to women experiencing a degree of empowerment and independence' (Kottegoda). K.C. Zachariah in his article 'Gender Dimensions of Migration in Kerala: Macro and Micro Evidence' a larger proportion of female return migrants are unemployed compared to male return migrants. This is similar to the general employment structure in India, where women's employment rate is low. Away from home people accepted to do work that they would never execute in their village due to the social stigma attached to it in their own culture, such as working as a house help. 'Migration helps maintain one's prestige by concealing one's occupation and by splitting the moment and site of wealth accumulation from its moment of consumption, enabling and encouraging a focus upon the result, cash earned' (Osella and Osella 117). Women's transnational movements affect the formation of social identities of both women and men. Gamburd has observed that a wife's transnational employment posed a tremendous threat to the masculinity of a husband and that he may compensate by indulging in drinking, gambling and womanizing. This behavior often resulted in abandonment or divorce. Female transnationalism may elevate existent stress between men and women 
but, on the other side, it may also have 'some positive effects for women such as increased self-esteem and self-confidence, and greater decision-making power. Thus, after their return home some women may continue to challenge the masculinity of their husbands' (Nielsen and Waldrop). After returning home the women undertake some additional responsibilities which were socially assigned to men such as disciplining children, supervising schoolwork and spending money - all of which suggests heightened agency. The amount of jointly performed tasks has been increased, indicating more equal gender roles within the family. Transnational employment helps in concealing one's occupation, thereby concentrating on the cash earned rather than how it is earned. Women's work often changes the identity politics for both men and women. Earlier, women migrated due to marriage which is now slowly gravitating towards economic pursuit. Women are no longer passive recipients, rather they have actively participated in Transnational process for employment, education etc. In this procedure, the gender roles undergo vast alterations and women are able to take their own decision for migration. Patriarchal structures are getting conciliatory with time in response to the changing power dynamics in the household. The expansion of the infrastructure like mass communication, education, economics, and healthcare services has 'elevated the position of women within families by increasing their access to various resources' (Oropesa). All these changes have enhanced women's ability to make their own choices in their lives and empowered them to take strategic decisions with respect to household matters including migration. In other words, women empowerment at the household level also gives women a say in the matter of migration decision for reasons other than marriage. Hence, it is significant to understand how women's empowerment acts as a significant predictor of female migration. The increased role of women in the household decision-making enables them to improve their 'self-determination, bargaining power, control over resources, and selfesteem, autonomy, status and power relations within a household context' (Shahnaz Parveen). According 
to Sandhya Rani Mahapatro , 'constraints on women's physical mobility in many parts of the world restrict their ability to make independent decisions. Women in countries such as India, Egypt, and Bangladesh are governed by social norms that restrict their physical mobility, and are referred to in the literature as female seclusion' (Mahapatro). This privacy involves the covering of face in some instances, as well as confinements on unaccompanied travel to such places as shops, pharmacies, or hospitals and limits on direct contact with unrelated males. Researches reveal the advancement of women's freedom of unhindered motion is a requirement for them to arrive at their own selections, to alter their mental postures, to improve their societal communication and so on. Therefore, the women who are capable of taking decisions on their chitchats \& visits to friends and relatives can also be expected to take decisions on migration. There is a huge variation of ideas in this respect. The proportion of women having the ability to take decisions on their own or with husbands with respect to visiting their friends and relatives ranges from 27 percent for Jammu to 57 percent for Kerala (Mahapatro 79). The empowerment of women in respect of domestic financial matters reflects their control over financial resources. Research reveals that women's command over fiscal affairs enhances empowerment of women, which successively heightens their engagement in the family financial decision. Many southern states of India, like Kerala, Karnataka and Andhra Pradesh where the migration rate is found high are able to participate in purchases of household durables. Like other indicators, moderate migration-moderate empowerment holds true for Orissa, Punjab, Uttaranchal and Gujarat. In states like Uttar Pradesh, Madhya Pradesh, Jharkhand, Jammu and Kashmir, the migration rate as well as the level of empowerment are low. The educational difference between husband and wife also determines the 'relative position of woman within a household' (Mahapatro 80). It is observed that if spousal educational departure is more, females have less authority in making choices compared to their male counterpart. Since migration is a matter decided within a family, a 
higher spousal educational difference is also expected to be a substantial forecaster of female Transnational movement. Kerala, Karnataka, AP and Maharashtra are the states falling high empowerment category. These are the states where the average educational difference between spouses is less than 2.5. Bengal, Uttaranchal, Orissa, Gujarat and Haryana show a moderate spousal educational difference is also moderate (2.5-3.5). Similarly under-developed states like Rajasthan, Bihar, UP, Jharkhand and Jam migration rate is low show a high spousal educational difference. This shows that a substantial number of states are equally distributed where empowerment relationship is found to be linear. Many researchers argue that women's empowerment is closely linked to the 'positive outcomes for families and societies. Following this line of argument, one can observe that migration of women, as an outcome of their empowerment, also holds few implications for the aggregate family well-being besides being an indicator of gender equality’ (Presser and Sen).

Empowerment of women, as a developmental indicator, may trigger changes in many other indicators. It reduces the gender gap in all major socio-economic indicators and enhances the status of women. In other words, women empowerment as an agency apart from increasing the socio economic condition of women itself, also enhances well being of other household members in terms of influencing the health, nutrition, education etc. Besides it also has economic implications by facilitating migration of females for enhancing their socio-economic status. Thus, 'empowering women is a crucial pathway for achieving development by reducing gender disparities in human development indicators and hence may ensure the achievement of all-round development of the society' (Mahapatro 83).

Migration produces contradictory outcomes. In most of the cases people have experienced economic improvement, but the social costs have been high for all and devastating for some. At the same 
time migration has paved the way for changing gender roles and relations. The success of migration 'depends to a great extent on the capacity of women and men to adapt and change their socially assigned roles so that they can work together to lift their household out of poverty' (Vadsemb).Women need to concretize their position in society by handling responsibility and exercising their agency. Women challenging the stereotypical gender roles must shoulder men's responsibilities. They may undertake Transnational migration to earn an income and become more assertive in their negotiations with husbands and other close relations. Transnationalism may have led to an extended agency for women because of either their experiences as de facto household heads or their own migration experiences. Thus, migration implies both continuity and change in women's agency and gender relations. 


\section{References}

Chant, Sylvia. Women-Headed Households: Diversity and Dynamics in the Developing World. London: MacMillan, 1997.

Gamburd, Michele Ruth. The Kitchen Spoon's Handle: Transnationalism and Sri Lanka's Migrant

Housemaids. New York: Cornell University Press, 2000.

Gulati, Leela. In the Absense of Their Men: The Impact of Male Migration on Women. New Delhi: Sage, 1993. International Jounal of English leaming and Teaching Shills

Kottegoda, Sepali. "Bringing Home the Money: Migration and Poverty in Gender Politics in Sri Lanka."

Poverty, Gender and Migration (2006): 71.

Mahapatro, Sandhya Rani. "Changing Gender Relations and Its Influence on Female Migration Decision in India." The Pakistan Development Review (2013): 78.

Nielsen, Kenneth Bo and Anne Waldrop, Women, Gender and Everyday Social Transformation in India.

New York: Anthem Press, 214.

Oropesa, R . "Development and Marital Power in Mexico." Social Forces (1997): 1291.

Osella, Filippo and Caroline Osella. "Migration, Money and Masculinity in Kerala." Journal of Royal Anthropological Institute (2000): 117.

Presser, H. and G Sen. Women's Empowerment and Demographic Processes: Moving Beyond Cairo. New York: Oxford University Press, 2000.

Reshmi, R S and Sayeed Unisa. "Economic Impact of Migration on the Family : The Case of International Female Labour Migration." India Migration Report (2013): 15. 
Shahnaz Parveen, Ingrid-Ute Leonhäuser. "Empowerment of Rural Woman in Bangladesh: A Household Level Analysis ." Conference on Rural poverty reduction Through Research for Development and Transformation. Dhaka, 2004. 62.

Singh, Supriya. Money, Migration, and Family : India to Australia. New York: Palgrave Macmillan, 2016.

Vadsemb, Berit Helene. "Gender Work and Social Change: Return Migration to Kerala." Women, Gender and Everyday Social Transformation in India. Ed. Kenneth Bo Nielsen and Anne Waldrop. London:

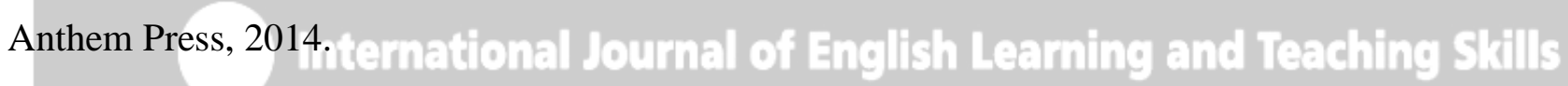

Vertovec, Steven. Transnationalism. Oxon: Routledge, 2009. 